\title{
KEPEMIMPINAN UNTUK MENDUKUNG KEBERHASILAN IMPLEMENTASI KEBIJAKAN KONSERVASI SUMBER DAYA ALAM
}

\author{
Tjahjo Tri Hartono \\ Peneliti pada Balai Besar Riset Sosial Ekonomi Kelautan dan Perikanan \\ JI. KS. Tubun Petamburan VI Jakarta 10260 \\ Telp. (021) 53650162, Fax. (021)53650159 \\ Diterima 2 Februari 2011 - Disetujui 11 Mei 2011
}

\begin{abstract}
ABSTRAK
Pada tahun 2020, Pemerintah Indonesia melalui Kementerian Kelautan dan Perikanan mentargetkan 20 juta hektar perairan (laut dan umum daratan) dapat ditetapkan sebagai kawasan konservasi perairan dan dikelola secara efektif. Pencapaian salah satu target pembangunan berkelanjutan di bidang kelautan dan perikanan ini perlu diperhatikan mengingat panjangnya sejarah konflik pengaturan pemanfaatan dan pengelolaan sumber daya di dalam kawasan konservasi. Untuk itu, dialog antar aktor, pihakpihak yang berpotensi untuk berkonflik, perlu dibangun bersama sejak sebuah wilayah dicadangkan dan selanjutnya ditetapkan sebagai kawasan konservasi perairan. Efektivitas dialog, yang diindikasikan oleh berbagai hal spesifik di lapangan, membutuhkan sosok-sosok aktor yang memiliki jiwa kepemimpinan. Melalui pemenuhan 5 (lima) faktor kepemimpinan, individu tersebut akan mengupayakan kelompoknya untuk menjadi organisasi pembelajar, yaitu organisasi yang senantiasa mampu melakukan perbaikan (continuous improvement) dalam rangka mereduksi dan mengelola konflik yang mungkin timbul karena diberlakukannya pengaturan dan pengelolaan sumber daya kelautan dan perikanan yang berbasis pada prinsip-prinsip konservasi di suatu wilayah.
\end{abstract}

Kata Kunci: kepemimpinan, konservasi, sumberdaya kelautan dan perikanan

\section{Pendahuluan}

Pembangunan berkelanjutan sejak tahun 1982 telah menjadi komitmen masyarakat dunia untuk dikedepankan dalam melaksanakan pembangunan. Melalui konsep ini pembangunan dilakukan berdasarkan pemenuhan tiga aspek, yaitu: kelestarian sumber daya alam dan lingkungannya (aspek ekologi), pemanfaatan sumber daya alam dan lingkungan yang memperhitungan kapasitas daya dukungnya (aspek ekonomi) dan adanya sistem distribusi manfaat pengelolaan sumber daya alam intra generasi dan antar-generasi (aspek sosial).

Sebagai bagian dari komitmen mewujudkan pembangunan berkelanjutan tersebut, sejak tahun 1990 pemerintah Indonesia telah menetapkan dan mengimplementasikan kebijakan konservasi². Berdasarkan kebijakan konservasi yang berlaku saat ini, konservasi dilakukan melalui penetapan dan kemudian pengelolaan sebuah kawasan konservasi untuk mencapai tujuan pengelolaan sumber daya alam yang sesuai dengan prinsip-prinsip konservasi ${ }^{1}$. Sebagai contoh, terkait dengan kebijakan ini pemerintah Indonesia melalui Kementerian Kelautan dan Perikanan (KKP) telah menargetkan penetapan dan terkelolanya kawasan konservasi untuk pelestarian sumber daya ikan secara efektif seluas 0,9 juta hektar pada tahun 2010 dan terus bertambah hingga 20 juta hektar pada tahun 2020 (Dit.KKJI 2010).

Optimisme atas terwujudnya pengelolaan kawasan konservasi di Indonesia secara efektif sebagaimana yang diharapkan tersebut di atas kiranya perlu dikaji kembali. Hal ini didasari pada fakta bahwa hingga kini di banyak bagian dunia masih terjadi konflik atas pengaturan pemanfaatan dan pengelolaan sumber daya di dalam kawasan konservasi, khususnya antara pihak pemerintah sebagai pengambil dan pelaksana kebijakan konservasi dengan masyarakat lokal yang secara tradisional merupakan pengguna sumber daya (user groups) di dalam kawasan konservasi (Abarkeli 2001).

Tulisan ini bertujuan memaparkan sebuah bangunan konsep kepemimpinan dalam mendukung keberhasilan implementasi kebijakan konservasi sumber daya alam. Bangunan konsep yang dimaksud disusun menggunakan beberapa teori, meliputi: teori konflik, teori rejim pengelolaan sumber daya alam, teori sumber daya milik bersama dan teori kepemimpinan.

${ }^{1}$ Berdasarkan Undang-Undang No. 5 Tahun 1990 Tentang Konservasi Sumber Daya Alam Hayati dan Ekosistemnya, konservasi adalah pengelolaan sumber daya alam hayati yang pemanfaatannya dilakukan secara bijaksana untuk menjamin kesinambungan persediaannya dengan tetap memelihara dan meningkatkan kualitas keanekaragaman dan nilainya.

${ }^{2}$ Berdasarkan Undang-Undang No. 5 Tahun 1990 Tentang Konservasi Sumber Daya Alam Hayati dan Ekosistemnya, Konservasi sumber daya alam hayati dan ekosistemnya dilakukan melalui kegiatan-kegiatan yang bertujuan untuk: a) perlindungan sistem penyangga kehidupan; b) pengawetan keanekaragaman jenis tumbuhan dan satwa beserta ekosistemnya; dan c) pemanfaatan secara lestari sumber daya alam hayati dan ekosistemnya. 


\section{Konflik dan Dinamika Rejim Pengelolaan Sumber Daya Alam}

Konflik adalah unsur terpenting dalam kehidupan manusia, karena manusia adalah makhluk yang selalu terlibat dalam perbedaan, pertentangan dan persaingan baik sukarela maupun terpaksa (Susan 2009). Konflik berarti pertentangan atau percekcokan. Pertentangan sendiri bisa muncul ke dalam bentuk pertentangan ide maupun fisik antara dua belah pihak berseberangan (Poerwadarminta 1976). Francis menambahkan unsur persinggungan dan pergerakan sebagai aspek tindakan sosialnya (Francis 2006). Sehingga secara sederhana, konflik adalah pertentangan yang ditandai oleh pergerakan dari beberapa pihak sehingga terjadi persinggungan.

Pengertian konflik di atas sesuai dengan apa yang pernyataan Pruit dan Rubin dengan mengutip Weber bahwa "konflik berarti persepsi mengenai perbedaan kepentingan (perceived divergence of interest), atau suatu kepercayaan bahwa aspirasi pihak-pihak yang berkonflik tidak dicapai secara simultan (Pruit dan Rubin 2004 dalam Susan 2009). Jika memahami konflik pada dimensi ini, maka unsur-unsur yang ada di dalam konflik adalah persepsi, aspirasi dan aktor yang terlibat di dalamnya (Susan 2009). Tidak mengherankan jika minimnya upaya mempertemukan dan mengharmonisasikan persepsi dan aspirasi antar pihak, sebagai sebuah bentuk resolusi konflik, berujung pada ketidakefektifan pengelolaan kawasan konservasi, yang berdampak pada terus berlanjutnya penurunan keanekaragaman hayati dan tingkat kesejahteraan masyarakat sekitar kawasan (Gerber et al 2009).

Terjadinya situasi tersebut di atas menunjukkan kurangnya pemahaman pemerintah terhadap pengelolaan kawasan konservasi sebagai sebuah arena politik besar dalam pengelolaan sumber daya milik bersama $^{3}$ (Ostrom 1990). Borrini-Feyebarend (2000) memaparkan masyarakat tradisional di masa lalu banyak terbentuk oleh sistem yang relatif tertutup, dan sumber daya alam dikelola melalui hubungan timbal-balik dan solidaritas yang kompleks. Sistem ini sepenuhnya tertanam dalam budaya lokal dan disesuaikan untuk perbedaan kekuasan dan peran, termasuk pengambilan keputusan dalam sebuah sistem yang holistik yang mencerminkan realitas dan makna. Dialog dan diskusi di antara pihak-pihak yang berkepentingan menjadi sebuah kebiasaan di masyarakat, dilandasi oleh nilainilai sosial yang terkait dengan pengambilan keputusan pengelolaan sumber daya alam berdasarkan biaya dan manfaat yang ditimbulkannya. Dengan kata lain, unit pengelolaan sumber daya alam dan unit kehidupan sosial dalam masyarakat tradisional cenderung berdampingan secara harmonis.

Sejarah menunjukkan munculnya kekuasaan kolonial dan negara-bangsa yang disertai dengan kekuasaan dan kewenangan mereka terhadap sumber daya alam telah menyebabkan matinya sistem pengelolaan sumber daya alam tradisional (BorriniFeyerabend 2000). Sistem ekonomi yang dibangun pada rejim ini cenderung melemahkan sistem ekonomi tradisional yang berbasis pada hubungan timbal balik dan solidaritas, yang pada hakikatnya berdasarkan kepada keharmonisan hubungan antara masyarakat dengan alam (Pomeroy 1995).

Kondisi tersebut di atas diperburuk dengan invasi pengetahuan "modern" yang lambat laun menjadikan pengetahuan dan keterampilan lokal menghilang dan menyebabkan semakin meningkatnya ketergantungan masyarakat lokal terhadap sistem ekonomi dan teknologi modern (Pomeroy 1995; Borrini-Feyerabend 2000). Lambat laun, ketergantungan atas sistem dan teknologi pengelolaan sumber daya alam pada rejim ini memicu terjadinya situasi ketidakberdayaan sekaligus ketidakbertanggungjawaban masyarakat lokal terhadap kelestarian sumber daya alam (Borrini-Feyerabend 2000).

Ketidakpahaman terhadap akar permasalahan dari ketidakefektifan pengelolaan sumber daya alam ini memicu berkembangnya pendekatan "top-down" terhadap pengelolaan kawasan konservasi. Keyakinan atas pendekatan ini menuntun pada dominasi intervensi pemerintah berupa tindakan mengklaim sumber daya alam sebagai hak milik negara (state property) dan pengaturan pemanfaatan dan pengelolaannya dilakukan oleh pemerintah (Abarkeli 2001; Hardin 1968 dalam Regmi 2007).

Pada umumnya, implementasi kebijakan konservasi berlandaskan pendekatan "top-down" ternyata lebih didasarkan pada pengelolaan aspek biologi semata dan cenderung mengabaikan pengetahuan dan sistem informasi informal (Abarkeli 2001; Pomeroy 2005). Ditambah dengan lemahnya perangkat pengawasan atas pelaksanaan aturan pengelolaan sumber daya alam di dalam kawasan konservasi, pendekatan ini ternyata justru tidak dapat menunjang tercapainya tujuan konservasi. Sebaliknya, pendekatan ini di banyak wilayah terbukti menyebabkan hilang atau terbatasnya sumber penghidupan, berubahnya relasi sosial dan fungsi ekologis kawasan konservasi bagi masyarakat lokal, yang berujung pada konflik antara mereka dengan pihak di luar mereka (pemerintah dan/atau organisasi non-pemerintah) (Dick and Mwangi 2008).

\footnotetext{
${ }^{3}$ Sumber daya milik bersama adalah komoditas (barang bernilai ekonomi) yang memiliki karakter sulit sekali atau perlu biaya besar untuk dapat mencegah pihak lain turut menikmati manfaatnya (non-excludability) dan jika dimanfaatkan akan mengurangi kesempatan pihak lain untuk dapat menikmati manfaatnya (rivalry) (Ostrom 1990). Pengelolaannya akan berkelanjutan hanya jika kelompok pengguna dapat teridentifikasi dengan baik atau mereka dapat mengeluarkan pihak lain diluar mereka yang juga berupaya menikmati manfaat dari pengelolaan sumber daya milik bersama tersebut (Ostrom 1990).
} 
Pada periode yang sama, hasil penelitian di berbagai belahan dunia menunjukkan kelompok masyarakat dapat mengatur sendiri (self governing) sumber daya alam dan lingkungannya dan hasilnya lebih baik dibandingkan pengaturan oleh pemerintah (Ostrom 1990). Bukti-bukti inilah yang selanjutnya memunculkan kembali (re-emerged) pendekatan pengembangan institusi ${ }^{4}$ pengelolaan sumber daya berbasis masyarakat (Community based-resource management) (Pomeroy et al 2001).

Community-based resource management (CBM) merupakan sebuah pendekatan "bottom up", yang pada hakikatnya merupakan sebuah upaya mewujudkan kembali pemenuhan keadilan sosial, pemanfaatan sumber daya alam secara berkelanjutan yang berasal dari inisiatif masyarakat (Borrini-Feyerabend 2000). Melalui pendekatan ini, keterlibatan masyarakat sebagai pihak pengguna sumber daya alam dan penggunaan institusi lokal dalam implementasi kebijakan pengelolaan sumber daya alam menjadi sebuah kondisi mutlak (Pomeroy 1995). Pilihan pendekatan ini didasari pada premis bahwa masyarakat lokal seharusnya menjadi pihak yang paling banyak menikmati dan sekaligus menanggung dampak negatif atas diimplementasikannya sebuah kebijakan; Oleh karena itu, sudah sepatutnya masyarakat lokal memiliki peran dan porsi yang besar di dalam pengambilan keputusan, bahkan hingga dapat mengatur sendiri pengelolaan sumber daya alam secara berkelanjutan (Tadjudin 2000).

\section{Dialog Pengelolaan Sumber Daya Alam yang Berkelanjutan}

Beberapa penelitian yang mengevaluasi dan kemudian mengkomparasi institusi pengelolaan kawasan konservasi laut negara-negara di Asia dan Kepulauan Karibia, telah menyepakati beberapa faktor yang mempengaruhi keberhasilan masyarakat dalam proses mengatur dirinya sendiri ${ }^{5}$ untuk mewujudkan pengelolaan kawasan konservasi secara berkelanjutan (Pomeroy et al. 1997; Pomeroy et al. 2001). Diperlukannya pemenuhan prinsipprinsip tersebut dilandasi oleh pentingnya pengaturan kewenangan para pihak yang berkepentingan (stakeholder), melalui sebuah proses dialog untuk pengambilan keputusan yang berkeadilan dalam rangka membangun aksi kolektif (collective action). Aksi kolektif yang dimaksud adalah kesamaan perilaku yang berhubungan dengan pencapaian tujuan pengelolaan kawasan konservasi itu sendiri
(Pomeroy et al. 2001; Pomeroy et al. 2004; Gerber et al 2009).

Pada hakikatnya, pembentukan dan pengelolaan kawasan konservasi secara efektif merupakan sebuah upaya mewujudkan institusi pengelolaan sumber daya milik bersama yang mapan atau berkelanjutan. Untuk dapat mencapai hal tersebut, pengelolaannya harus dapat mempertahankan akses dan manfaat yang selama ini telah dimiliki oleh masyarakat lokal terhadap sumber daya di dalam kawasan konservasi. Tentunya, sepanjang kedua hal tersebut masih selaras dengan kapasitas daya dukung lingkungan kawasan konservasi itu sendiri.

Situasi tersebut di atas membutuhkan dialog antar pihak yang berkepentingan dengan masyarakat lokal atau di sekitar kawasan konservasi. Tujuannya adalah terwujudnya aksi kolektif pengelolaan kawasan konservasi yang sesuai dengan prinsip-prinsip konservasi. Aksi kolektif yang dimaksud hanya akan terwujud jika terbangun kejelasan atas kewenangan (authority) dan pengaturannya di antara para pihak dimaksud. Jika tidak, institusi yang ada hanya akan mengarahkan pengelolaan sumber daya kawasan konservasi kepada situasi open access (Abarkeli 2001).

Dari hasil kajian terhadap berbagai literatur yang terkait (Bodin and Crona 2009; Gerber et al 2008; Ostrom 2002; Pomeroy et al 2001), dapat dikemukakan bahwa para pihak harus berdialog atau terlibat dalam rangka menentukan kewenangan dan pengaturannya atas sumber daya milik bersama. Hal ini selaras dengan pernyataan beberapa peneliti lainnya bahwa kebijakan publik yang menjadi produk wacana (discourses) kebijakan pengelolaan sumber daya milik bersama umumnya dihasilkan oleh pengetahuan kolektif sebuah jaringan (networks) yang didalamnya terdiri atas berbagai aktor yang saling terkait (interrelated actors) melalui suatu hubungan sistematis (Klijn 1997).

Mengacu pada tulisan Pomeroy et al (2001), diketahui bahwa jaringan yang dimaksud terdiri atas 4 (empat) kelompok aktor, yaitu: kelompok pemerintah, kelompok di luar masyarakat (agen eksternal), kelompok masyarakat pengguna sumber daya dan individu-individu anggotanya. Dari sudut pandang konflik, perlunya dialog dibangun di dalam maupun antar keempat kelompok aktor ini karena konflik bisa muncul pada skala yang berbeda seperti konflik antar orang (interpersonal conflict), konflik antar kelompok (intergroup conflict), konflik antar kelompok dengan negara (vertical conflict) bahkan konflik antar negara (interstate conflict) (Susan 2009).

${ }^{4}$ Institusi dapat diartikan sebagai aturan (formal dan informal) yang dipahami dan dilaksanakan oleh sebuah masyarakat (Hess and Ostrom 2007). Aturan tersebut diberlakukan di masyarakat untuk membatasi terjadinya penyimpangan atau tindakan yang tidak diinginkan. Oleh karena itu, efektivitas institusi diindikasikan oleh adanya pihak-pihak yang mampu mengatur besarnya hak para pihak dan memberikan sanksi pada mereka yang tidak patuh terhadap implementasi pengaturan hak tersebut (Jepperson 1991 dalam Bandaragoda 2000; North 1990; Crawford dan Ostrom 2005).

${ }^{5}$ Proses ini dikenal sebagai pencapaian ideal tahapan co-management, dimana pengelolaan sumber daya alam diatur sendiri oleh masyarakat dan pemerintah hanya mendapat informasi perkembangan institusi tersebut (Berkes et al 2001; Jentoft 2005; Pomeroy et al 2005). 
Lebih lanjut, Pomeroy et al (2001) menjelaskan dialog antar aktor ditujukan untuk menyediakan sebuah atau seperangkat regulasi yang didalamnya mengandung beberapa ketentuan sebagai berikut: (1) kejelasan dan legitimasi kewenangan berbagai pihak untuk menentukan hak kepemilikan (property rights) atas sumber daya milik bersama; (2) kejelasan dan legitimasi hak pemilikan berbagai pihak terhadap sumber daya milik bersama; (3) kejelasan tanggung jawab kelompok masyarakat lokal terhadap kewenangan yang dimiliki mereka atas pengelolaan sumber daya milik bersama; (4) hak dan tanggung jawab mitra masyarakat lokal dalam pengelolaan sumber daya milik bersama; (5) dukungan terhadap transparansi penetapan dan penegakan institusi lokal; dan (6) legitimasi kewenangan kelompok masyarakat lokal untuk menyelenggarakan institusi yang ditujukan bagi pemenuhan kebutuhan hidup mereka.

Pomeroy et al (2001) juga menjelaskan dialog antar para pihak memerlukan kehadiran aktoraktor kelompok di luar masyarakat non pemerintah (lembaga penelitian, lembaga pendidikan maupun lembaga swadaya masyarakat). Kehadiran aktor-aktor kelompok ini diharapkan mengakselerasi terwujudnya institusi pengelolaan sumber daya milik bersama yang mapan terkait dengan beberapa hal sebagai berikut: (1) membantu masyarakat lokal untuk mengidentifikasi permasalahan (konflik kepentingan) sebagai diskursus (wacana) penetapan institusi pengelolaan sumber daya milik bersama yang dibutuhkan; (2) memberi saran, gagasan untuk penyelesaian masalah pengembangan institusi pengelolaan sumber daya milik bersama; dan (3) memberi asistensi, pelatihan dan bimbingan teknis terkait peningkatan kapasitas masyarakat untuk penyelesaian masalah dan pengembangan kemitraan dalam rangka penerapan institusi pengelolaan sumber daya milik bersama sebagaimana dibutuhkan.

Di tingkat kelompok masyarakat, hasil rangkuman pernyataan beberapa ahli disimpulkan bahwa dialog yang terjadi terkait upaya mewujudkan beberapa hal sebagai berikut (Folke et al 2005): (1) pengetahuan kolektif (common knowledge) terhadap jenis dan besaran sumber daya milik bersama serta ukuran kelompok (anggota) yang dibolehkan untuk mewujudkan kewenangan dalam pemanfaatan dan pengelolaan sumber daya milik bersama dengan baik; (2) kelompok masyarakat yang homogen (etnis, kekerabatan, religi dan/atau teknologi pemanfaatan sumber daya) dan dengan jumlah anggota yang relatif kecil terkait dengan pemanfaatandan pengelolaansumberdayamilikbersama; (3) Pengurangan stratifikasi sosial dan kesamaan (equal) akses dengan pihak elite lokal terhadap pemanfaatan dan pengelolaan sumber daya alam; (4) Organisasi kelompok masyarakat pengguna yang terlegitimasi kewenangannya oleh seluruh pihak untuk mengatur pemanfaatan dan pengelolaan sumber daya alam; (5) Kerja sama antara kelompok dengan pemerintahan dan tokoh masyarakat lokal untuk mendukung pengembangan institusi pengelolaan sumber daya alam berbasis masyarakat; (6) Mitra dan kemitraan untuk mewujudkan institusi pengelolaan sumber daya milik bersama; (7) Komitmen semua pihak untuk bertanggung jawab dalam penegakan institusi pengelolaan sumber daya milik bersama; (8) Mekanisme pengelolaan konflik terkait dengan penentuan kewenangan dan pengaturan kewenangan terkait dengan pengelolaan sumber daya milik bersama;

Di tingkat individu yang menjadi anggota kelompok, dialog antar aktor terkait dengan beberapa hal sebagai berikut: (1) Insentif ekonomi berupa pendapatan dan kecukupan pangan; (2) Kelestarian sumber daya milik bersama yang menjadi sumber penghidupan dan kesejahteraan setiap individu pengguna dan keluarganya di masa depan; dan (3) Insentif sosial berupa pengakuan dan legitimasi dari berbagai pihak (khususnya pemerintah) terhadap akses dan hak milik setiap individu terkait dengan pemanfaatan dan pengelolaan sumber daya di sekitarnya.

\section{Penutup: Kepemimpinan dan Dialog Antar Aktor}

Hal-hal yang menjadi bahan dialog antar aktor di masing-masing tingkatan tersebut di atas pada hakikatnya menggambarkan serangkaian kegiatan sebuah organisasi pengelolaan sumber daya alam yang spesifik, yang dirancang untuk pencapaian sebuah tujuan yang diketahui dengan jelas di dalam sebuah organisasi. Di dalam organisasi terbangun jaringan antar aktor yang saling tergantung berdasarkan adanya pemahaman atas kesamaan nilai ${ }^{6}$ dan persepsi ${ }^{7}$ yang merupakan dasar penggerak aktivitas mereka.

Dunia pada era globalisasi adalah kompleks dan berubah terus menerus. Oleh karena itu, suatu organisasi harus memiliki kemampuan untuk mengelola perubahan (managing change), khususnya pengetahuan (knowledge) mengenai situasi lingkungan dan aktoraktor yang berkepentingan dengannya (Clegg et al. 2005). Tanpa kemampuan tersebut, suatu organisasi akan senantiasa dihadapkan pada kondisi ketidakpastian yang pada akhirnya berakibat fatal bagi pencapaian tujuan maupun keberlangsungan organisasi itu sendiri.

Sebuah organisasi akan memiliki keunggulan komparatif dibandingkan organisasi lainnya apabila

\footnotetext{
${ }^{6}$ Nilai adalah arahan perilaku aktor dan menjadi motivasi untuk mencapai sebuah tujuan. (Hermans LM, WAH Thiessen. 2009. Actor Analysis Methods and Their Use for Public Policy Analysts. European Journal for Operational Research 196: 809.

${ }^{7}$ Persepsi adalah pandangan, kepercayaan, pengetahuan atau referensi (acuan) para aktor terkait dengan lingkungannya, baik dengan aktor lainnya, jaringan sosial lainnya maupun substansi permasalahan yang dihadapinya. Ibid.
} 
sang manajer dapat mengantisipasi setiap perubahan lingkungan tanpa harus senantiasa melakukan perubahan struktur atau reframing organisasi (Clegg 2003). Disinilah sang manajer dituntut untuk melakukan sebuah inovasi dalam reframing organisasi. Inovasi yang dimaksud adalah membentuk organisasinya menjadi sebuah organisasi pembelajar (learning organization). Learning organization dapat diartikan sebagai suatu organisasi yang memfasilitasi pembelajaran bagi setiap anggotanya untuk secara sadar dan bersama-sama dengan anggota lainnya untuk meningkatkan kapasitas dirinya untuk menciptakan hasil yang diinginkan (Pedler et al. 1997; Senge 1990).

Sebagai seorang manajer, diperlukan kepemimpinannya (leadership) dalam serangkaian upaya untuk mewujudkan organisasinya sebagai organisasi pembelajar. Senge (1990) memberi lima faktor yang perlu dipenuhi untuk itu, mencakup:

a) Personalmastery, belajar untuk memperluas kapasitas personal dalam mencapai hasil kerja yang paling diinginkan, dan menciptakan lingkungan organisasi yang menumbuhkan seluruh anggotanya untuk mengembangkan diri mereka menuju pencapaian sasaran dan makna bekerja sesuai dengan harapan yang mereka pilih;

b) Mental models, proses bercermin, sinambung memperjelas dan meningkatkan gambaran diri kita tentang dunia luar, dan melihat bagaimana mereka membentuk keputusan dan tindakan kita;

c) Shared vision, membangun rasa komitmen dalam suatu kelompok, dengan mengembangkan gambaran bersama tentang masa depan yang akan diciptakan, prinsip dan praktek yang menuntun cara kita mencapai tujuan masa depan tersebut;

d) Team learning, mentransformasikan pembicaraan dan keahlian berpikir (thinking skills), sehingga suatu kelompok dapat secara sah mengembangkan otak dan kemampuan yang lebih besar disbanding ketika masing-masing anggota kelompok bekerja sendiri;

e) System thinking, cara pandang, cara berbahasa untuk menggambarkan dan memahami kekuatan dan hubungan yang menentukan perilaku dari suatu sistem. Faktor disiplin kelima ini membantu untuk melihat bagaimana mengubah sistem secara lebih efektif dan untuk mengambil tindakan yang lebih pas sesuai dengan proses interaksi antara komponen suatu sistem dengan lingkungan alamnya.

\section{Daftar Pustaka}

Abarkeli S. 2001. A Critique of Development and Conservation Policies in Environmentally Sensitive Regions in Brazil. Geoforum 32: 551565.
Bodin O, BI Crona. 2009. The role of social networks in natural resources governance: What relational patterns make a difference? Gobal Environmental Change 19: 366-374.

Borrini-Feyerabend G. 2000. Co-management of Natural Resources: Organising, Negotiating and Learning by Doing. Yaoundé: IUCN.

Bromley, DW. Editor. 1992. Making the Commons Work. San Francisco: Institute for Contemporary Studies.

Bromley DW \& MM Cernea. 1989. The management of common property natural resources: some conceptual and operational fallacies. World Bank Discussion Paper 57. Washington DC.: World Bank.

Clegg S, M. Komberger, T. Pitsis. 2005. Managing and Organizations: An Introduction to Theory and Practice. London: Sage Publications.

Clegg S. 2003. Theorizing "Globalization" Sociologically For Management. Gestão.Org, 1(1):5-26.

Dick-Meinzen R and Mwangi E. 2008. Cutting the web of interests: Pitfalls of formalizing property rights. Land Use Policy 26: 36-43.

[Dit. KKJI] Direktorat Konservasi Kawasan dan Jenis Ikan. 2010. Rencana Strategis Direktorat Konservasi Kawasan dan Jenis Ikan Tahun 2010-2014. Jakarta: Direktorat Konservasi Kawasan dan Jenis Ikan, Direktorat Jenderal Kelautan, Pesisir dan Pulau-pulau Kecil, Kementerian Kelautan dan Perikanan.

Folke C, T Hahn, P Olsson, J Norberg. 2005. Adaptive governance of social-ecological systems. Annual review of Environment and Resources 30: 441473.

Francis D. 2006. Teori Dasar Transformasi Konflik Sosial. Yogyakarta: Penerbit Quills.

Gerber JD, P Knoepfel, S Nahrath, F Varone. 2009. Institutional Resources Regimes: Towards sustainability trough the combination of property rights theory and policy analysis. Ecological Economics 698: 798-809.

Klijn EH. 1997. Policy networks: An overview. In: Kickert, WJM. EH Klijn, JFM Koppenjan (Eds.). Managing Complex Networks. London: Sage. pp. 14-34.

Ostrom E. 2002. Type of Good and Collective Action. Paper presented on February 22, 2002 at Workshop in Political Theory and Policy Analysis, Bloomington, Indiana University.

1990. Governing the Commons. The Evolution of institutions for Collective Action. Cambridge: Cambridge University Press.

Pedler M., Burgogyne J. and Boydell T. 1997. The Learning Company: A strategy for sustainable development. 2nd Ed. London; McGraw-Hill. 
Poerwadarminta WJS. 1976. Kamus Besar Bahasa Indonesia. Jakarta: Balai Pustaka.

Pomeroy RS. 1995. Community-based and comanagement institutions for sustainable coastal fisheries management in Southeast Asia. Ocean \& Coastal Management Vol.27 (3): 143-162.

Pomeroy RS, RB Polnac, BM Katon, CD Predo. 1997. Evaluating factors contributing to the success of community-based coastal resource management: the Central Visayas Regional Project-1, Philippines. Ocean \& Coastal Management. Vol.36: 97-120.

Pomeroy RS, Brenda MK, Ingvild H. 2001. Conditions affecting the success of fisheries comanagement: lessons from Asia. Marine Policy 25: 197-208.
Pomeroy RS, P McConney, R Mahon. 2004. Comparative analysis of coastal resource co-management in the Carribean. Ocean \& Coastal Management 47: 429-447.

Regmi AR. 2007. The Role of Heterogeneity In Collective Action: A Look at the Intertie between Irrigation and Forests, Case Studies From Chitwan, Nepal. Indiana: School of Public and Environmental Affairs, Indiana University.

Senge PM. 1990. The Fifth Discipline. London: Century Bussiness.

Susan M. 2009. Sosiologi Konflik dan Isu-isu Konflik Kontemporer. Jakarta: Kencana Media Group.

Tadjudin D. 2000. Manajemen Kolaborasi. Bogor: Pustaka Latin. 